\title{
Higher Financial Incentives Policy and the Impact to the Employee/s Intention to Leave: A Systematic Literature Review
}

\author{
Dynna Dwi Puspita* \\ The Audit Board of Republic of Indonesia, Indonesia
}

\section{ARTICLE INFORMATION}

\section{Article history:}

Data submission : August 21, 2019

$1^{\text {st }}$ revision: September 20, 2019

Accepted: November 20, 2019

Available online: December 12, 2019

Keywords: Incentive, Financial, Employee, Institution, Intention to Leave.

\begin{abstract}
The aim of this literature study is to determine the relationship between institutional policies that implement high financial incentives and the employee's intention to leave. A systematic literature review was applied to examine the relationship between institutional policies and employee intention to leave. This study is motivated by the result of previous research studies which showed high interest in resigning at the Audit Board of Republic of Indonesia (BPK). Meanwhile BPK loses many employees each year because of the retired, died and resigned. Due to recruiting requires a lot of resources, and then they issue a policy to raise the employee's financial incentives in order to reduce their employees's intention to leave. Therefore, this study proposes a framework for studying relation and impact of this higher financial incentive on their employee's intention to leave. Based on this study, the officials can be using this finding to evaluate the implement of their policy and to take necessary approach in order to reduce high turnover rate in their institution.
\end{abstract}

2019 FIA UB. All rights reserved.

\section{Introduction}

Employees are valuable assets of every company especially service based company. They are the main key to the business. How employees are treated and how much they value the company they work for, will have an impact on how the organization performs. The utilization of human resources will determine the achieving company goals. In consequence, as primary assets, employees have to organize well. According to Malcolm Baldrige theory in high quality concept: Focus on human resources is the fifth category from the Baldrige criteria. This category assesses the system works, motivation and employee in establishing conditions that are aligned with the goals and actions of the company (Al Mamun \& Hasan, 2017).

However, in the current era, competition does not only occur between job seekers but also companies. While many companies are competing to recruit the best employees who fit the company's vision, on the contrary, others will certainly try to retain their employees.

This has also further stimulated the phenomenon of employee's intention to leave their company and move to others. For companies, this becomes serious problem. More employees who leave force the company to recruit new one. It takes a lot of considerable resources in time, cost and energy.

The employee's intention to leave problem not only occurs in private companies but also public sector organization, as in the Audit Board of Republic of Indonesia (BPK). BPK was established in January 1947, headquartered in Magelang Central Java. During several periods, this institution experienced many changes and developments. After the reform era, BPK is the only one institution as a government external audit institution. The State Financial Management and Accountability

\footnotetext{
* Corresponding author email: dynna@gmail.com
} 
Act 2004 (No.15 of 2004) emphasized the position of BPK as the sole external auditor of state finance, and that its role as an independent and professional institution.

The responsibility of auditing state finances in all these regions encouraged the BPK to establish representatives in each province in Indonesia. In consequence, it has many employees. As of December 2018, BPK had 8.288 employees.

This institution's core business is in auditing activities of state financial. Hence, auditors become their primary resource. Auditor is one of the professions that have high levels of job switching (Suwandi, 1999). Though the auditors's status is State Civil Apparatus, the turnover rate among them has become necessary issue for past few years.

Every year, BPK loses many auditors due to retired, died and resigned. The data from internal human resources information system declared BPK loses 15-20 employees in average, each year. The data also showed number of auditors who resigned is relatively high. Over last ten years (until December 2018) there were at least 145 auditors was resigned.

To replace the retired, died and resigned, BPK should recruit new auditors. As a public sector organization, in recruiting new employees BPK is bounds by many regulations and requires approval from the Central Government through the Ministry of Empowerment of State Apparatus and Beaurocracy Reform. Institutions cannot immediately recruit new ones when needed.

In addition, auditor is a prophecy requires specific knowledge and experience. Newly recruited auditor cannot directly have the equivalent ability of senior auditors. Therefore, BPK provides education and special training for they newly recruited auditor. These recruiting and training processes needs high cost and long time.

Due to the employees who retired and died cannot be avoided, to solve the problem of employee shortages then the intention of auditors to leave should be minimized. BPK then issues the policy to raise incentives to their employees since February 2018. The Central Government gave an approval through Presidential Regulation Number 84/2018. The issuance of this policy is expected to reduce employee interest in resigning. The pay level dimension has a higher correlation with intention to leave than other dimensions like affective commitment (Santoso et al, 2018).

Based on above mentioned studies and facts, this literature review will focus on wheter there is a relationship between giving higher incentive policy to the employee's intention to leave. This study aims to provide a framework for studying the impact of the policy to the employee's turnover problem.

\section{Discussion}

\subsection{Financial incentive}

One of the goals of an employee in a company is to earn income in the form of wages or incentives. Incentives received to fulfill their basic needs such as food, clothing and housing. Each company in determining the amount of wages paid to employees must be appropriate, so that the lowest wages are given to meet their living needs (Belete, 2018).

Gunawan and Amalia (2015) emphasized that wage flexibility is the main topic of economics, mostly found in the literature related to the provision of incentives provided by companies. A number of theoretical models have developed explanations about the importance and how companies should design compensation schemes to encourage employees to work for the benefit of the company.

Rynes et. al (2004) on their research pointed out that many survey results that concluded that financial rewards were not realy important were wrong. They proved that in surveys, respondents often answered that financial rewards were not the main thing in choosing a job, but their research showed that employee behavior showed the opposite. In many cases, employees resign because the wage problem they receive is not enough to satisfy them.

\subsection{Intention to leave}

Intention to leave can be defined as the desire of individuals to leave the organization and look for other alternative jobs (Suwandi \& Indriantoro, 1999). This intention to leave refers to the results of individual evaluations regarding the continuation of their relationship with the organization and has not been realized in the definite actions of leaving the organization. The turnover can occur voluntarily and involuntary.

Employees who leave the organization due to voluntary reasons can be categorized as avoidable voluntary turnover and unavoidable voluntary turnover. Avoidable voluntary turnover can be caused by reasons in the form of salary; work whisperer, employer or any other organization that is felt well, while voluntary work transfers that cannot be avoided can be caused by changes in career path or family factors (Fitriany, 2011). The intention to leave the organization discussed in this study is in the context of the voluntary turnover model and is seen as a function of job satisfaction.

Disgruntled employees will look for another place that provides a higher salary. To keep high-performing 
employees from leaving their current jobs, usually companies will offer inducements in the form of higher incentives and promotions. This inducement can eliminate dissatisfaction, which will then affect turnover intention.

\subsection{Previous result studies}

Organizational commitment divides into three types: (1) Affective commitment, an organizational commitment that arises because of the emotional attachment, intention of employees to engage and identify themselves with the company. In this case the employee decides to stay in an organization because of his own will. (2) Continuance commitment, a commitment to organization based on considerations about what have to be sacrified when he leaving the organization. This commitment is related to their fears of losing benefits in the organization where he works. (3) Normative commitment, a commitment in the form of employee beliefs about his responsibilities to the organization. The obligation to be loyal to the organization making the employees decides to remain in the organization.

Several previous studies have examined the relationship between the turnover rate of BPK employees and organizational commitment and job satisfaction. Organizational commitment negatively affects the auditors' intention to leave on BPK auditors meanwhile burnout has a positive effect on turnover intentions (Kim \& Cho, 2016). That result study was consistent with the results of research conducted by Pamungkas (2015), which showed that the BPK auditor had a strong affective and ongoing commitment and did not significantly influence the desire of his employees to leave. Whereas normative commitment has shown the opposite.

In addition, results of study on BPK auditors showed positive relationship between job satisfaction and employees intention to leave. The result had also affected by respondend ages. The age of the young respondents made the desire of the auditors to find other better jobs was high (Pamungkas, 2015).

\subsection{The impact of higher incentive to the employee's intention to leave}

However, there are limitations to the previous studies above. The study generally only looked at the relationship between the employee's desire to leave with organizational commitment and job satisfaction. In addition, the small and uneven number of respondents from age groups and positions can cause bias in the results of research.

The above research has not added other variables such as job stress and employee replacement patterns. In accordance with the characteristics of institutions that exist in all regions of Indonesia at the provincial level, internal employee replacements at the BPK are also an important point in making decisions to resign.

The strategy of how to minimize employee turnover is confronted with several policy options, improving existing policies for recruitment, training, and payment of wages (Ongori, 2007). For BPK, the solution to recruiting new employees is bound by many regulations and involving many institutions. Recruitment of new employees cannot be done immediately when needed. Likewise, by improving employee-training policies, it takes a long time and a lot of money to produce qualified and experienced auditors.

The best option is to provide more benefits to existing employees and reduce their desire to move. BPK has issued a policy to increase financial incentives for its employees, especially higher for its auditors, since February 2018. With this significant increase, it can be re-tested its effect on the level of the resigning. Wheter there is a strong negative relationship between financial rewards (remuneration, cash incentives, work life balance, supervisor support and employee recognition) and turnover intention. The reward system is effective and attractive to employees and their turnover intention will be reduced gradually (Mendis, 2017).

Similarly, research findings conducted by Alzayed and Murshid (2017) in Ministry of Information di Kuwait showed that the perception of employee commitment (appreciation and recognition, job security and organizational justice) has a significant negative effect on employee intentions to leave. Thus, decision makers in the Ministry direct their human resources policies and strategies to concentrate more on the application of fairness and equality among employees regarding performance appraisals, salary increases, bonuses, as well as gifts and awards and recognition. Human resource management needs to increase the level of satisfaction among employees through increasing their level of willingness and desire to give higher effort and maximum contribution to the work by showing appreciation and rewarding them appropriately, which will motivate them and increase their level of job satisfaction. Top management in the ministry had revised its current policies and strategies and modifying them well to retained employees and stopped them from leaving the ministry.

The objective of this study in examining the relationshipship between high financial incentives and intention to leaves can use guidelines that can provide illustrations of theoretical construction models and interesting variables, in the form of a framework. Conceptual frameworks show how researchers perceive 
the concepts involved in research, especially the relationship between concepts (Al Mamun \& Hasan, 2017). Designing a conceptual model begins with a thorough literature review. Therefore, Mendis (2017 develop a conceptual framework based on the causes and factors that affect employee turnover, habits in the organization and the right strategies to minimize employee turnover. This framework is considered suitable for use in this study.

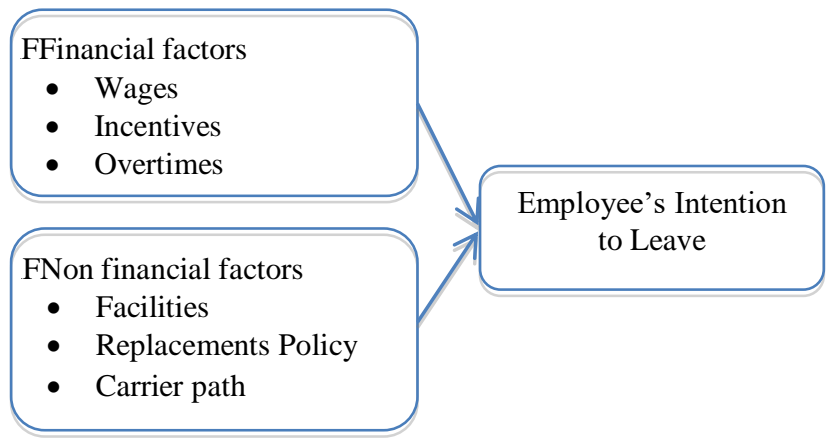

Figure 1. Conceptual Framework

\section{Conclusion}

This study investigates the relationship between high financial incentives and employee intentions to leave work. By providing empirical evidence on this perception, this research can support officials to identify problems. For future going concern, institutions must recognize internal potential to face future challenges. Leaders' policies, decisions and actions will greatly affect employees.

Officials must identify precisely the main source of employee intention to leave, so they can establish the right policies, decisions and actions to retain employees in their organization. Officials must understand that employees in their organizations must be treated as liquid assets of the organization. This asset needs to be monitored carefully; otherwise their organization faces difficulties. Salary and pay related variables have a large influence on employee turnover. Management must adequately compensate employees. They must pay employees based on their performance and in addition they must provide incentives to employees such as individual bonuses, lump sum bonuses, profit sharing, and other benefits. Therefore, if this is implemented it will be able to minimize employee turnover.

The limitation of this study is that it only uses financial incentives as a factor or dependent variable, while many other factors can influence an employee's decision to leave. Therefore, it is recommended that subsequent reviews include other factors such as organizational culture, internal replacement pattern policies and career paths in the institution.

\section{References}

Al Mamun, C.A \& Hasan, MD. (2017). Factors Affecting Employee Turnover and Sound Retention Strategies in Business Organization: A Conceptual View. Problems and Perspectives in Management. 15(1):63-71.

Alzayed, M. \& Murshid, M.A. (2017). Factors Influencing Employees' Intention to Leave Current Employment in the Ministry of Information in Kuwait. European Journal of Business and Management. 9(12).

Belete, A.. (2018). Turnover Intention Influencing Factors of Employees: An Empirical Work Review. International Journal of Research in Business Studies and Management. 5(7): 23-31.

Cho, Y.J. \& Lewis, G.B. (2011). Turnover Intention and Turnover Behaviour: Implications for Retaining Federal Employees. Review of Public Personnel Administration. $\mathrm{XX}(\mathrm{X}): 1-20$.

Fitriany, A. (2011). Analisis Faktor yang Mempengaruhi Kepuasan Kerja Auditor dan Hubungannya dengan Kinerja dan Keinginan Berpindah Kerja Auditor. Jurnal Akuntansi dan Keuangan Indonesia. 8(2):171-196.

Gunawan, H. \& Amalia, R. (2015). Wages and Employees Performance: The Quality of Work Life as Moderator. International Journal of Economics and Financial Issues. (5):349-353.

Hudaib, M. \& Cooke, T.E. (2005). The Impact of Managing Director Changes and Financial Distress on Audit Qualification and Auditor Switching. Journal of Business Finance and Accounting. 32(9\&10):1703-1739.

Kim, Y. \& Cho, Y.C. (2016). Impact of retirement System on Job Satisfactio and Loyalty: A Case of The Salary Peak System. International Business \& Economics research Journal. 15(1).

Mendis, M.V.S. (2017). The Impact of Reward System on Employee Turnover Intention: A Study on Logistics Industry of Sri Lanka. International Journal of Scientific \& Technology Research. 6(9).

Ongori, H. (2007). A Review of the Literature on Employee Turnover. African Journal of Business Management. 049-054.

Pamungkas, S.C. (2015). Komitmen Organisasi, Kepuasan Kerja dan Turnover Intentions Auditor Badan Pemeriksa Keuangan Republik Indonesia. Jurnal Akuntansi dan Bisnis. 16(1):61-74.

Robbins, S.P. \& Judge, T.A. (2015). Organizational Behaviour. New Jersey: Perason Education Inc.

Rynes, S.L., Gerhart, B. \& Minette, K.A. (2004). The Importance of Pay in Employee Motivation: Discrepancies between What People Say and What They Do. Wiley InterScience. 43(4): 381-394.

Santoso, A.L., Sitompul, S.A. \& Budiatmanto, A. (2018). Burnout, Organizational Commitment and 
Turnover Intention. Journal of Business and Retail Management Research (JBRMR). 13(1).

Suwandi, I.N. (1999). Pengujian Model Turnover Pasewark dan Strawser, Studi Empiris pada Lingkungan Akuntan Publik. Jurnal Riset Akuntansi Indonesia. 2(2):173-195. 